\title{
Tea saponin reduced methanogenesis in vitro but increased methane yield in lactating dairy cows
}

\author{
J. Guyader, ${ }^{*}$ M. Eugène, ${ }^{*}$ M. Doreau, ${ }^{*}$ D. P. Morgavi, ${ }^{*}$ C. Gérard, $†$ and C. Martin ${ }^{* 1}$ \\ *UMR1213 Herbivores, INRA, VetAgro Sup, Clermont Université, Université de Lyon, F-63122 Saint-Genès-Champanelle, France \\ †NEOVIA by InVivo, Talhouët, F-56250 Saint-Nolff, France
}

\begin{abstract}
The effect of tea saponin supplementation in the ruminant diet on methane emissions, rumen fermentation, and digestive processes is still under debate. The objective of this study was to assess the effect of this plant extract on methanogenesis, total-tract digestibility, and lactating performances of dairy cows. The work included 2 independent and successive experiments. First, the effect of 7 tea saponin doses (from 0 to 0.50 $\mathrm{g} / \mathrm{L}$ ) on methane emissions and protozoa concentrations was tested in 2 repeated in vitro batch culture incubations using bovine rumen contents as inoculum and a cereal mixture as substrate. After $18 \mathrm{~h}$ of incubation, total gas production and composition as well as rumen fermentation parameters and protozoa concentration were analyzed. Increasing dosage of the plant extract reduced methane production and protozoa concentration, with a maximum reduction of $29 \%$ for $\mathrm{CH}_{4}(\mathrm{~mL} / \mathrm{g}$ of substrate) and $51 \%$ for protozoa $\left(10^{5} / \mathrm{mL}\right)$. Tea saponin did not affect volatile fatty acids concentration, but marginally decreased total gas production by $5 \%$ at the highest dose. Second, a 2-period crossover design experiment was carried out with 8 lactating dairy cows fed a basal diet (54\% corn silage, $6 \%$ hay, and $40 \%$ pelleted concentrates on a dry matter basis) without (control) or with $0.52 \%$ tea saponin (TSP). Each experimental period lasted $5 \mathrm{wk}$. Animals were fed ad libitum during the first $3 \mathrm{wk}$ of the period (wk 1, 2, and 3 ) and restricted (95\% of ad libitum intake) during the last $2 \mathrm{wk}$ (wk 4 and 5). Intake and milk production were recorded daily. Methane emissions were quantified using open chambers ( $2 \mathrm{~d}$, wk 4$)$. Total-tract digestibility and nitrogen balance were determined from total feces and urine collected separately ( $5 \mathrm{~d}$, wk 5 ). Rumen fermentation parameters and protozoa concentration were analyzed from samples taken after morning feeding ( $1 \mathrm{~d}$, wk 5). Milk production, dry matter intake,
\end{abstract}

Received June 21, 2016.

Accepted November 22, 2016.

${ }^{1}$ Corresponding author: cecile.martin@inra.fr and feed efficiency were reduced with TSP $(-18,-12$, and $-8 \%$, respectively). As daily methane production (g/d) was not affected, methane emissions ( $\mathrm{g} / \mathrm{kg}$ of dry matter intake) increased by $14 \%$ with TSP. Total-tract digestibility and nitrogen balance were similar between diets, except for acid detergent fiber digestibility, which tended to be improved with TSP $(+4$ percentage units). Rumen fermentation parameters and protozoa concentration were relatively unchanged by diets. Under the conditions of this experiment, tea saponin is not efficient to reduce methane emissions from dairy cows. Key words: dairy cow, methane, rumen fermentation, tea saponin

\section{INTRODUCTION}

Saponins have an inhibitory action toward protozoa by affecting cell membrane integrity (Goel and Makkar, 2012). This biological property has been used to implement dietary $\mathrm{CH}_{4}$ mitigation strategies in ruminants, as protozoa are known to be positively correlated with methanogenesis (Guyader et al., 2014). For instance, Wang et al. (2012) reviewed the possible antimethanogenic potential of tea saponin. Using rumen inoculum from sheep fed $60 \%$ forage for in vitro experiments, $\mathrm{Hu}$ et al. (2005b) and Guo et al. (2008) reported a $\mathrm{CH}_{4}$ reduction of 14 and $8 \%$ (mL/g of substrate, DM basis), respectively, when using $0.24 \mathrm{~g} / \mathrm{L}$ of pure tea saponin powder mixed with a substrate containing 50\% hay. However, the $\mathrm{CH}_{4}$-mitigating effect of this plant extract in vivo remains controversial. Yuan et al. (2007), Mao et al. (2010), and Zhou et al. (2011) reported a significant decrease of $\mathrm{CH}_{4}$ emissions ( $\mathrm{g} / \mathrm{kg}$ of DMI $-9,-27$, and $-11 \%$, respectively) and protozoa concentrations $(-42 \%$ on average, expressed as a percent of bacterial $16 \mathrm{~S}$ rDNA) in sheep fed $60 \%$ forage mixed with $0.50 \%$ tea saponin powder in DM. In contrast, a similar dosage of tea saponin included in pelleted concentrates did not reduce methanogenesis in nonlactating dairy cows fed $50 \%$ forage (Guyader et al., 2015a). A lower dosage $(0.37 \%$ tea saponin powder in DM, mixed with diet) also failed to reduce $\mathrm{CH}_{4}$ emissions in steers fed 
85\% (DM basis) concentrate diet (Ramírez-Restrepo et al., 2016). Such a discrepancy could be related to differences in feed retention times within the rumen as influenced by the level of intake and composition of basal diet (Kumar et al., 2009; Martin et al., 2010), or in the quality of the plant extract among experiments (Li and Powers, 2012). The effect of tea saponin supplementation on $\mathrm{CH}_{4}$ production and protozoa population of lactating dairy cows has never been tested.

Aside from its potential $\mathrm{CH}_{4}$-mitigating effect, tea saponin may have a beneficial effect on fiber digestibility. Indeed, whereas other sources of saponins, such as Quillaja saponaria or Yucca schidigera, have no effect on diet digestibility (Lila et al., 2005; Pen et al., 2007; Holtshausen et al., 2009), tea saponin improved in vitro OM digestibility (21\%; Wei et al., 2012) and numerically increased NDF digestibility in nonlactating dairy cows (2 percentage units; Guyader et al., 2015a).

The objective of the current study was to clarify the effect of tea saponin on methanogenesis and protozoa concentrations as well as its effect on diet digestibility of cattle. A dose-response in vitro experiment was designed to evaluate the efficacy of the commercial tea saponin extract to decrease $\mathrm{CH}_{4}$ production and protozoa concentrations. An in vivo experiment was then conducted to test the effect of tea saponin supplementation on diet digestibility, milk production, and methane emission of lactating dairy cows.

\section{MATERIALS AND METHODS}

In both experiments, a tea saponin extract containing $689 \mathrm{~g}$ of pure tea saponin $/ \mathrm{kg}$ of DM was used (Choisun Tea Sci-Tech Co. Ltd., Hangzhou, Zhejiang, China).

\section{In Vitro Experiment}

Batch Culture Incubations. Two repeated batch culture incubations were conducted to assess the effectiveness of a tea saponin extract to reduce $\mathrm{CH}_{4}$ production and protozoa concentrations. Incubations were carried out in 120-mL bottles containing $400 \mathrm{mg}$ of substrate, $15 \mathrm{~mL}$ of rumen fluid as inoculum, and $25 \mathrm{~mL}$ of an anaerobic buffer solution (Goering and VanSoest, 1970). On a DM basis, the ground substrate (1-mm screen) was composed of wheat $(50.5 \%)$, corn (30.0\%), dehydrated beet pulp $(8.2 \%)$, calcium carbonate $(3.4 \%)$, urea $(2.4 \%)$, beet molasses $(2.0 \%)$, binder (2.0\%), and mineral-vitamin mix (1.5\%). The OM, CP, starch, NDF, and ADF content of the substrate were $92.2,18.1,50.8,12.8$, and $4.6 \%$ of DM, respectively. Seven concentrations of pure tea saponin were tested $(0,0.04,0.08,0.12,0.15,0.30$, and $0.50 \mathrm{mg} / \mathrm{mL})$, with dosages selected according to previous in vitro experi- ments with tea saponin ( $\mathrm{Hu}$ et al., 2005a; Guo et al., 2008; Arhab et al., 2014). Within each incubation, every treatment was assayed in duplicate.

Rumen fluid inoculum was prepared from strained (polyester monofilament fabric, $250 \mu \mathrm{m}$ pore size) and pooled whole ruminal contents collected manually before feeding from 3 cannulated nonlactating dairy cows receiving (DM basis): 38\% corn silage, 32\% natural grass hay, and $30 \%$ concentrate $(30 \%$ dehydrated beet pulp, $23 \%$ wheat, $20 \%$ barley, $15 \%$ rapeseed meal, $7.8 \%$ soybean meal, $1.5 \%$ cane molasses, $1.0 \%$ dicalcium phosphate, $0.6 \%$ salt, $0.5 \%$ magnesium carbonate, $0.5 \%$ premix, $0.05 \%$ fungicide, and $0.03 \%$ aroma). Animals were adapted to their diets during 3 wk before the first sampling. Inoculum was mixed with the substrate and the anaerobic buffer under a $\mathrm{CO}_{2}$ stream into prewarmed $\left(39^{\circ} \mathrm{C}\right)$ incubation bottles. The bottles were then sealed with a butyl rubber stopper and incubated anaerobically at $39^{\circ} \mathrm{C}$ for $18 \mathrm{~h}$.

Sampling and Gas Measurement. At the end of the incubation, gas production in each bottle was measured with a pressure transducer. Gas samples were collected with 10 -mL syringes for $\mathrm{CH}_{4}$ and $\mathrm{H}_{2}$ concentration analysis by GC with a thermal conductivity detector (Micro GC 3000, Agilent Technologies, France; Morgavi et al., 2013). Bottles were then opened and pH was immediately measured on the total mixed content with a portable $\mathrm{pH}$ meter (CG840, electrode $\mathrm{Ag} / \mathrm{AgCl}$, Schott Geräte, Hofheim, Germany). Samples from total mixed content were taken for VFA analysis $[0.8 \mathrm{~mL}$ of medium in $0.5 \mathrm{~mL}$ of a $0.5 \mathrm{M} \mathrm{HCl}$ solution containing $2 \%$ (wt/vol) metaphosphoric acid and $0.4 \%$ (wt/vol) crotonic acid] and protozoa counting [ $2 \mathrm{~mL}$ of medium in $2 \mathrm{~mL}$ of a $0.06 \%$ (wt/vol) methyl green-formalin solution]. Samples for VFA analysis were kept at $4^{\circ} \mathrm{C}$ for $2 \mathrm{~h}$ before being centrifuged at 16,500 $\times g$ for $10 \mathrm{~min}$ at $4^{\circ} \mathrm{C}$. Supernatant was collected and stored at $-20^{\circ} \mathrm{C}$ before VFA analysis by GC with a flame ionization detector (Morgavi et al., 2008). Samples for protozoa counting were stored at room temperature and in the dark until counting by microscopy (Ogimoto and Imai, 1981), and concentrations were $\log _{10}$-transformed before statistical analysis.

\section{In Vivo Experiment}

The experiment was conducted at INRA's SaintGenès-Champanelle research center in France from January to May 2014. All procedures involving animals were performed in accordance with the French Ministry of Agriculture and the European guidelines (European Parliament and Council of the European Union, 2010) for regulations of animal research and experimentation (approval number 01784.01). 
Experimental Design and Animal Feeding. Eight lactating Holstein cows (4 primiparous and 4 multiparous) habituated to handling were used. At the beginning of the experiment, the average BW was 617 $\pm 51 \mathrm{~kg}($ mean $\pm \mathrm{SD})$, milk production was $29 \pm 7.3$ $\mathrm{kg}$, and DIM was $106 \pm 21 \mathrm{~d}$. Cow BW did not change throughout the experiment, as animals weighed $608 \pm$ $33 \mathrm{~kg}$ at the end of the experiment. Cows were separated in 2 groups balanced for parity, DIM, and milk production. The experimental protocol followed a $2 \times 2$ crossover design $(2$ periods $\times 2$ treatments), with each experimental period lasting 5 wk $(35 \mathrm{~d})$ with the last 2 wk for measurements (wk 4 and 5; d 22 to 35 ). From d 1 to 17 , cows were housed in a freestall barn with an individual trough accessible via an electronic tag. Starting on d 18 and until the end of the period, animals were attached individually in tiestalls except for $2 \mathrm{~d}$ in wk 4, during which animals were maintained in open-circuit respiration chambers. Therefore, animals had $4 \mathrm{~d}$ during the adaptation weeks to adapt to the housing conditions of measurement weeks. In addition, all cows were already used to tiestall conditions including $\mathrm{CH}_{4}$ chambers, as they previously participated in similar experimental design.

Group of cows were fed a control treatment (CON) or CON supplemented with $0.76 \%$ tea saponin extract corresponding to $0.52 \%$ pure tea saponin in DM included in pelleted concentrates (TSP). Percentage of pure tea saponin in total diet was chosen based on previous in vivo experiments on cattle (Guyader et al., 2015a) and sheep (Mao et al., 2010). On a DM basis, diets were made of $54 \%$ corn silage, $6 \%$ permanent grassland hay, and $40 \%$ pelleted concentrates, which were mainly composed of corn (30\%), soybean hulls (17\%), wheat bran (15\%), and soybean meal (13\%; InVivo NSA, Longué-Jumelles, France; Table 1). Diets were equivalent in starch, CP, and NDF contents (28.0, 16.1, and $35.4 \%$ of DM on average, respectively). During the experiment, corn silage mixed with concentrates was offered twice daily $(66 \%$ at $0930 \mathrm{~h}$ and $34 \%$ at 1600 h) as a TMR. Hay was offered once daily (0800 h) and before the TMR to ensure intake of fiber and prevent ruminal acidosis.

Unlike other experiments, in the present study and in Guyader et al. (2015a), tea saponin was included in pelleted concentrates for a better palatability of the product and to be representative of possible on-farm conditions of application. One can argue that inclusion of the plant extract in pellets influences its $\mathrm{CH}_{4}$-mitigating efficiency as a result of a degradation of the saponin active compound during heating required for the pelleting process. However, saponins have good heat resistance and losses of saponins have only been observed with temperatures above $80^{\circ} \mathrm{C}$ (Oenning et al., 1994; Tarade et al., 2006); in the present work the pelleting process was carried out at a lower temperature $\left(\sim 40^{\circ} \mathrm{C}\right)$.

Two weeks before starting the experiment, cows were fed ad libitum with CON. Throughout the experiment cows were fed ad libitum, except during measurement weeks in which offered feed was restricted to $95 \%$ of individual voluntary feed intake to ensure full consumption of the diet including tea saponin. For cows fed TSP, the CON concentrate was progressively replaced with the TSP concentrate at the beginning of each experimental period to achieve the maximal tea saponin dose in $1 \mathrm{wk}$. Cows had free access to water throughout the experiment.

Intake and Feed Chemical Analyses. Throughout the experiment, offered feed was weighed and recorded daily to estimate DMI. One sample of corn silage, hay, and concentrates was taken on $2 \mathrm{~d}$ during wk 4 and 5 . For each sample, one aliquot was used to determine $\mathrm{DM}\left(103^{\circ} \mathrm{C}\right.$ for $\left.24 \mathrm{~h}\right)$ and another aliquot was stored at $4^{\circ} \mathrm{C}$ (hay and concentrates) or $-20^{\circ} \mathrm{C}$ (corn silage). At

Table 1. Ingredients and chemical composition of the experimental diets

\begin{tabular}{|c|c|c|}
\hline \multirow[b]{2}{*}{ Item } & \multicolumn{2}{|c|}{$\operatorname{Diet}^{1}$} \\
\hline & $\mathrm{CON}$ & TSP \\
\hline \multicolumn{3}{|l|}{ Ingredients, $\%$ of DM } \\
\hline Corn silage ${ }^{2}$ & 54.0 & 54.0 \\
\hline Hay & 6.0 & 6.0 \\
\hline \multicolumn{3}{|l|}{ Pelleted concentrate } \\
\hline Corn & 11.9 & 11.9 \\
\hline Barley & 3.36 & 2.96 \\
\hline Soybean meal & 5.24 & 5.24 \\
\hline Rapeseed meal & 2.00 & 2.00 \\
\hline Soybean hulls & 6.60 & 6.60 \\
\hline Wheat bran & 6.00 & 5.24 \\
\hline Dehydrated beet pulp & 0.94 & 0.94 \\
\hline Urea & 0.80 & 0.80 \\
\hline Calcium carbonate & 1.13 & 1.13 \\
\hline Dicalcium phosphate & 0.44 & 0.44 \\
\hline Beet molasses & 1.20 & 1.60 \\
\hline Mineral-vitamin mix & 0.20 & 0.20 \\
\hline Salt & 0.17 & 0.17 \\
\hline Fungicide & 0.02 & 0.02 \\
\hline Aroma $^{3}$ & 0.02 & 0.02 \\
\hline Tea saponin extract ${ }^{4}$ & 0.00 & 0.76 \\
\hline \multicolumn{3}{|c|}{ Chemical composition, \% of DM (unless otherwise noted) } \\
\hline $\mathrm{OM}$ & 93.0 & 93.1 \\
\hline $\mathrm{CP}$ & 16.1 & 16.1 \\
\hline $\mathrm{NDF}$ & 35.1 & 35.6 \\
\hline $\mathrm{ADF}$ & 18.4 & 18.7 \\
\hline Starch & 28.2 & 27.8 \\
\hline Gross energy, $\mathrm{MJ} / \mathrm{kg}$ of $\mathrm{DM}$ & 17.7 & 17.9 \\
\hline
\end{tabular}

${ }^{1} \mathrm{CON}=\operatorname{diet}$ control; $\mathrm{TSP}=\operatorname{diet} \mathrm{CON}$ containing $0.52 \%$ tea saponin on a DM basis.

${ }^{2}$ Fermentation characteristics of fresh silage juice: $\mathrm{pH}=3.57$; acetic acid $=0.74 \mathrm{~g} / 100 \mathrm{~g}$; lactic acid $=3.01 \mathrm{~g} / 100 \mathrm{~g} ; \mathrm{N}^{-N_{H}}=0.02 \mathrm{~g} / 100 \mathrm{~g}$. ${ }^{3}$ Gusti, Nutriad, Chester, UK.

${ }^{4} 689 \mathrm{~g}$ of saponins/ $\mathrm{kg}$ of DM according to supplier (Choisun Tea SciTech Co. Ltd., Hangzhou, Zhejiang, China) indications. 
the end of the experiment, feed samples were pooled per treatment, freeze-dried, and ground (1-mm screen) before analyses (InVivo Labs, Chierry, France) of ash, $\mathrm{CP}, \mathrm{NDF}, \mathrm{ADF}$, starch, and gross energy (GE) content as described in Guyader et al. (2016).

Methane Emissions. Total $\mathrm{CH}_{4}$ emissions were determined individually for 2 consecutive days per cow in wk 4 of each experimental period using 4 open-circuit respiration chambers. As a consequence of chambers availability, measurements were staggered over $4 \mathrm{~d}$ : on d 1 and $2, \mathrm{CH}_{4}$ emissions of 4 cows $(2$ cows fed CON, 2 cows fed TSP) were measured, the rest being determined on $\mathrm{d} 3$ and 4.

Details on chambers design and associated analytical equipment are given in Guyader et al. (2015b). Briefly, the chambers operated at a slight negative pressure, with an air flow oscillating between 700 and $800 \mathrm{~m}^{3} / \mathrm{h}$. Airflow in each chamber was continuously measured (CP300, KIMO, Montpon-Ménestérol, France) and recorded with 1 data point every 5 min (KT-210-AO, KIMO). Concentration of gases in the ambient air and in each chamber was alternatively analyzed for 5 min every $25 \min (0.1-\mathrm{Hz}$ sample frequency) using an infrared detector (Ultramat 6, Siemens, Karlsruhe, Germany) and recorded (Nanodac Invensys, Eurotherm Automation SAS, Dardilly, France). The detector was manually calibrated the day before each 2 -d measurement period using pure $\mathrm{N}_{2}$ (blank) and a mixture of $\mathrm{CH}_{4}(650 \mathrm{ppm})$ and $\mathrm{CO}_{2}(700 \mathrm{ppm})$ in $\mathrm{N}_{2}$.

Chambers rear doors were opened twice daily for cleaning and milking, and front doors were opened 3 times per day at each feed distribution. In total, doors were opened 3 times per day, representing $1 \mathrm{~h}$ of work per day on average. As much as possible, work in chambers was planned to avoid doors opening during the 5 -min gas analysis period. When this was not possible, missing data were extrapolated by mobile average of adjacent data (before and after chamber disturbance occurred). On average, 30 min of data were discarded per day and per chamber. Methane emissions were calculated as the difference between chamber and ambient $\mathrm{CH}_{4}$ concentrations multiplied by the airflow corrected for environmental parameters (temperature, relative humidity, and pressure; Pinares-Patiño et al., 2012).

Milk Yield and Composition. Cows were milked twice daily and daily milk production was quantified throughout the experiment. During $1 \mathrm{~d}$ in wk 4 and $1 \mathrm{~d}$ in wk 5, milk composition was determined at morning and afternoon milking on samples $(30 \mathrm{~mL})$ mixed with potassium bichromate (Merck, Fontenay Sous Bois, France), and immediately stored at $4^{\circ} \mathrm{C}$ for further analyses. Milk fat, CP, and lactose content were analyzed by infrared spectrometry with a 3-channel spectrophotometer (Galilait, Theix, France; method 972.16;
AOAC, 1990) and urea concentration was determined by colorimetry (Galilait; Potts, 1967). Daily fat- and protein-corrected milk (FPCM) production was calculated from daily milk production and composition (Gerber et al., 2011) as follows:

$$
\begin{gathered}
\text { FPCM }(\mathrm{kg} / \mathrm{d})=\text { milk }(\mathrm{kg} / \mathrm{d}) \\
\times[0.337+0.116 \times \text { fat }(\%)+0.06 \times \operatorname{protein}(\%)] .
\end{gathered}
$$

Digestibility and Nitrogen Balance. Total-tract digestibility of nutrients and $\mathrm{N}$ balance were determined via daily total and separate collection of feces and urine during $5 \mathrm{~d}$ in wk 5 . To separate urine from feces, cows were fitted with a urine-collection device connected to a 30-L flask containing $500 \mathrm{~mL}$ of $3 \mathrm{M}$ sulfuric acid to keep a urine $\mathrm{pH}$ lower than 3 and avoid $\mathrm{N}$ volatilization (Doreau et al., 2014). Each day, after weighing and mixing of feces, 1 aliquot (1\%) was used to determine $\mathrm{DM}\left(103^{\circ} \mathrm{C}\right.$ for $\left.24 \mathrm{~h}\right)$ and another aliquot (1\%) was sampled and pooled per week and per animal before freezing $\left(-20^{\circ} \mathrm{C}\right)$. At the end of the experiment, samples were defrosted, homogenized, and freeze-dried before grinding (1-mm screen). Chemical composition (OM, NDF, ADF, and CP) was analyzed similarly to feed.

Urine was also weighted daily and 1 aliquot (1\%) was pooled per week and per animal before freezing $\left(-20^{\circ} \mathrm{C}\right)$. At the end of the experiment, samples were defrosted and $\mathrm{N}$ content was determined according to Kjeldahl method (InVivo Labs; method 2001.11, AOAC International, 2005).

Rumen Sampling. Rumen content was sampled in the ventral sac of each cow by stomach tubing at 1300 $\mathrm{h}$ (i.e., $3.5 \mathrm{~h}$ after the last morning feed distribution) on the last day of wk 5 (Shen et al., 2012). Rumen samples were strained through a polyester monofilament fabric (250 $\mathrm{mm}$ pore size) and filtrate was subsampled for determination of VFA, ammonia $(1 \mathrm{~mL}$ of filtrate in $0.1 \mathrm{~mL}$ of $5 \%$ orthophosphoric acid), and protozoa concentrations. Samples for $\mathrm{NH}_{3}$ analyses were stored at $-20^{\circ} \mathrm{C}$ before analysis by colorimetry (Weatherburn, 1967). Samples for VFA analyses and protozoa counting were treated as described for the in vitro experiment. Moreover, protozoa were categorized as either small $(<100 \mu \mathrm{m})$ or large $(>100 \mu \mathrm{m})$ entodiniomorphs or as holotrichs (Dasytricha or Isotricha; Williams and Coleman, 1992).

\section{Statistical Analyses}

All statistical analyses were carried out with the MIXED procedure in SAS (version 9.2; SAS Inst. Inc., Cary, NC). For the in vitro experiment, data from du- 
plicate bottles were averaged within incubation. The effect of tea saponin on gas production, rumen fermentation parameters, and protozoa concentration was tested with the dose as a fixed effect and incubation as a random effect. The linear dose-response effect of the plant extract was tested by adding the CONTRAST statement after calculating coefficients for unequally spaced orthogonal contrasts with the IML procedure of SAS.

For the in vivo experiment, 1 animal was culled during the second period after an injury not related to the trial. All data for this animal were deleted in statistical analyses. The statistical model included the animal as random effect $(\mathrm{n}=7)$, and the fixed effects of diet ( $\mathrm{n}$ $=2)$, period $(\mathrm{n}=2)$, sampling day $(\mathrm{n}=8$ for milk production; $\mathrm{n}=2$ for methane and milk composition; $\mathrm{n}=5$ for nutrients intake), and the associated interactions (diet $\times$ sampling day and diet $\times$ period). Sampling days were treated as repeated measurements with compound symmetry as the covariance structure based on Akaike's information criteria. Least squares means are reported throughout with the pooled standard error of the mean derived from the model. Differences between diets were tested with the PDIFF option and considered significant at $P<0.05$, whereas trends were discussed at $0.05 \leq P \leq 0.1$.

\section{RESULTS}

\section{In Vitro Experiment}

Tea saponin powder decreased total gas and $\mathrm{CH}_{4}$ production $(P<0.001)$ without modification of $\mathrm{H}_{2}$ production (Table 2). Compared with the control, $\mathrm{CH}_{4}(\mathrm{~mL} / \mathrm{g}$ of substrate) was reduced by $29 \%$ with the highest dose of saponin. Addition of the plant extract did not affect total VFA concentration and final $\mathrm{pH}$, but modified the VFA profile. Increasing doses of tea saponin reduced acetate and butyrate proportions $(P=0.001)$ and increased propionate proportion $(P<0.001)$, which resulted in lower acetate-to-propionate and (acetate + butyrate)-to-propionate ratios $(P<0.001)$. Protozoa concentration was linearly reduced with increasing tea saponin doses (Pearson correlation coefficient $=$ $-0.860, \mathrm{n}=14 ; P<0.001)$, with a maximum reduction of $51 \%$ (expressed as $10^{5} / \mathrm{mL}$ ) with $0.50 \mathrm{~g} / \mathrm{L}$ of tea saponin $(P<0.001)$.

\section{In Vivo Experiment}

Milk Production and Methane Emissions. Diet TSP reduced milk and FPCM production by $18(P<$ $0.001)$ and $16 \%(P<0.001)$, respectively, without affecting milk composition in fat $(32.7 \mathrm{~g} / \mathrm{kg}$, on average),

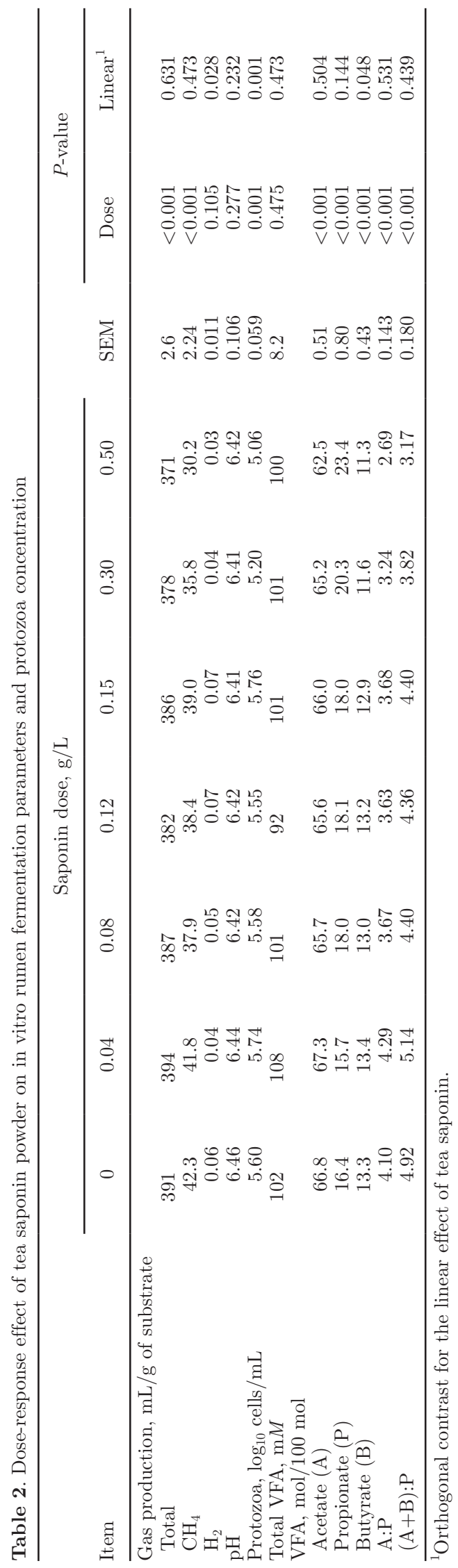

Journal of Dairy Science Vol. 100 No. 3, 2017 
Table 3. Milk production and milk composition of lactating dairy cows fed a diet containing tea saponin $(\mathrm{n}=7)$

\begin{tabular}{|c|c|c|c|c|}
\hline \multirow[b]{2}{*}{ Item $^{1}$} & \multicolumn{2}{|c|}{ Diet $^{2}$} & \multirow[b]{2}{*}{ SEM } & \multirow[b]{2}{*}{$P$-value } \\
\hline & $\mathrm{CON}$ & TSP & & \\
\hline \multicolumn{5}{|c|}{ Production, $\mathrm{kg} / \mathrm{d}$} \\
\hline Milk & 28.0 & 23.0 & 2.04 & $<0.001$ \\
\hline $\mathrm{FPCM}^{3}$ & 25.0 & 21.0 & 1.98 & $<0.001$ \\
\hline \multicolumn{5}{|c|}{ Composition, $\mathrm{g} / \mathrm{kg}$} \\
\hline Fat & 31.3 & 34.1 & 1.85 & 0.324 \\
\hline $\mathrm{CP}$ & 31.5 & 30.8 & 0.59 & 0.406 \\
\hline Lactose & 51.2 & 50.9 & 0.62 & 0.709 \\
\hline \multicolumn{5}{|l|}{ Yield, g/d } \\
\hline Fat & 916 & 802 & 97.5 & 0.186 \\
\hline $\mathrm{CP}$ & 922 & 735 & 72.1 & $<0.001$ \\
\hline Lactose & 1,497 & 1,215 & 100.5 & $<0.001$ \\
\hline \multicolumn{5}{|l|}{ Feed efficiency } \\
\hline Milk/DMI & 1.41 & 1.31 & 0.070 & 0.001 \\
\hline $\mathrm{FPCM} / \mathrm{DMI}$ & 1.26 & 1.20 & 0.066 & 0.037 \\
\hline
\end{tabular}

${ }^{1}$ Milk production: data from 8 sampling days (4 d in wk 4 and $4 \mathrm{~d}$ in wk 5); Milk composition: data from 2 sampling days ( $1 \mathrm{~d}$ in wk 4 and $1 \mathrm{~d}$ in wk 5 ). Feed efficiency was calculated using DMI associated with the period of milk production measurement.

${ }^{2} \mathrm{CON}=$ diet control; TSP $=$ diet $\mathrm{CON}$ containing $0.52 \%$ tea saponin on a DM basis.

${ }^{3} \mathrm{FPCM}$ : fat- and protein-corrected milk $=$ milk yield $(\mathrm{kg} / \mathrm{d}) \times[0.337+0.116 \times$ fat $(\%)+0.06 \times \mathrm{CP}(\%)]$

(Gerber et al., 2011).

$\mathrm{CP}(31.2 \mathrm{~g} / \mathrm{kg}$, on average $)$, and lactose $(51.1 \mathrm{~g} / \mathrm{kg}$, on average; Table 3). However, TSP reduced protein and lactose yields $(-20$ and $-19 \%$, respectively; $P<$ 0.001). Feed efficiency was also lower with TSP (-7 and $-5 \%$ when expressed in $\mathrm{kg}$ of milk $/ \mathrm{kg}$ of DMI and $\mathrm{kg}$ of $\mathrm{FPCM} / \mathrm{kg}$ of DMI, respectively; $P<0.05$ ).

Expressed in grams per day or grams per kilogram of digested NDF, $\mathrm{CH}_{4}$ emissions were similar between CON and TSP (Table 4). Inversely, cows fed TSP produced more $\mathrm{CH}_{4}$ when expressed in grams per kilogram of DMI $(+14.0 \%$; $P<0.001)$, grams per kilogram of milk $(+20.6 \% ; P<0.001)$, grams per kilogram of di- gested DM $(+12.3 \% ; P<0.001)$, grams per kilogram of digested $\mathrm{OM}(+12.1 \% ; P<0.001)$, or as a percentage of GE intake $(+12.9 \% ; P<0.001)$.

Diet Digestibility and $\boldsymbol{N}$ Balance. Diet TSP reduced daily DMI $(-2.4 \mathrm{~kg} / \mathrm{d}, P<0.001)$ as well as $\mathrm{OM}$ $(-2.2 \mathrm{~kg} / \mathrm{d}, P<0.001)$, NDF $(-0.7 \mathrm{~kg} / \mathrm{d}, P<0.001)$, $\operatorname{ADF}(-0.4 \mathrm{~kg} / \mathrm{d}, P<0.001)$, and GE $(-38 \mathrm{MJ} / \mathrm{d}, P$ $<0.001$ ) intake (Table 5). Nutrient digestibility (DM, $\mathrm{OM}, \mathrm{NDF}$, and $\mathrm{CP}$ ) was similar between diets with an average DM digestibility of $66.4 \%$, but TSP tended to improve ADF digestibility $(+4.0$ percentage units; $P=$ $0.080)$. Nitrogen intake and $\mathrm{N}$ released in urine $(\mathrm{g} / \mathrm{d})$

Table 4. Methane production of lactating dairy cows fed a diet containing tea saponin $(\mathrm{n}=7)$

\begin{tabular}{|c|c|c|c|c|}
\hline \multirow[b]{2}{*}{$\mathrm{CH}_{4}{ }^{1}$} & \multicolumn{2}{|c|}{ Diet $^{2}$} & \multirow[b]{2}{*}{ SEM } & \multirow[b]{2}{*}{$P$-value } \\
\hline & $\mathrm{CON}$ & TSP & & \\
\hline $\mathrm{g} / \mathrm{d}$ & 388 & 395 & 35.2 & 0.694 \\
\hline $\mathrm{g} / \mathrm{kg}$ of $\mathrm{DMI}$ & 19.1 & 22.2 & 0.88 & $<0.001$ \\
\hline $\mathrm{g} / \mathrm{kg}$ of milk & 13.5 & 17.0 & 1.12 & $<0.001$ \\
\hline $\mathrm{g} / \mathrm{kg}$ of digested DM & 29.1 & 33.2 & 1.32 & $<0.001$ \\
\hline $\mathrm{g} / \mathrm{kg}$ of digested $\mathrm{OM}$ & 30.5 & 34.7 & 1.37 & $<0.001$ \\
\hline $\mathrm{g} / \mathrm{kg}$ of digested NDF & 113 & 119 & 4.3 & 0.208 \\
\hline$\%$ of gross energy intake ${ }^{3}$ & 5.4 & 6.2 & 0.25 & $<0.001$ \\
\hline
\end{tabular}

${ }^{1}$ Methane production (g/d, g/kg of DMI, $\mathrm{g} / \mathrm{kg}$ of milk, \% of gross energy intake): data from 2 sampling days in wk 4. For methane expressed as a function of digested nutrients, nutrient intake associated with the chamber period ( $2 \mathrm{~d}$ in wk 4$)$ was multiplied by the digestibility coefficients obtained in wk 5.

${ }^{2} \mathrm{CON}=\operatorname{diet}$ control; $\mathrm{TSP}=\operatorname{diet} \mathrm{CON}$ containing $0.52 \%$ tea saponin on a DM basis.

${ }^{3} \mathrm{CH}_{4}(\%$ gross energy intake $)=\left[\mathrm{CH}_{4}(\mathrm{MJ} / \mathrm{d}) /\right.$ gross energy intake $\left.(\mathrm{MJ} / \mathrm{d})\right] \times 100$. Daily $\mathrm{CH}_{4}$ production in MJ was calculated from $\mathrm{CH}_{4}$ in $\mathrm{g} / \mathrm{d}$ and the volumic energy of $\mathrm{CH}_{4}$ combustion $\left(35.6 \mathrm{MJ} / \mathrm{m}^{3}\right.$; Okun, 2009). 
Table 5. Daily nutrient intake, total-tract digestibility, and $\mathrm{N}$ balance of lactating dairy cows fed a diet containing tea saponin $(\mathrm{n}=7)$

\begin{tabular}{|c|c|c|c|c|}
\hline \multirow[b]{2}{*}{ Item $^{1}$} & \multicolumn{2}{|c|}{ Diet $^{2}$} & \multirow[b]{2}{*}{ SEM } & \multirow[b]{2}{*}{$P$-value } \\
\hline & $\mathrm{CON}$ & TSP & & \\
\hline \multicolumn{5}{|l|}{ Daily nutrient intake } \\
\hline $\mathrm{DM}, \mathrm{kg} / \mathrm{d}$ & 20.0 & 17.6 & 1.19 & $<0.001$ \\
\hline $\mathrm{OM}, \mathrm{kg} / \mathrm{d}$ & 18.6 & 16.4 & 1.11 & $<0.001$ \\
\hline $\mathrm{NDF}, \mathrm{kg} / \mathrm{d}$ & 7.01 & 6.29 & 0.422 & $<0.001$ \\
\hline $\mathrm{ADF}, \mathrm{kg} / \mathrm{d}$ & 3.68 & 3.30 & 0.221 & $<0.001$ \\
\hline Gross energy, MJ/d & 353 & 315 & 21.2 & $<0.001$ \\
\hline \multicolumn{5}{|c|}{ Total-tract digestibility, \% } \\
\hline DM & 65.9 & 66.8 & 0.75 & 0.362 \\
\hline $\mathrm{OM}$ & 67.6 & 68.5 & 0.75 & 0.359 \\
\hline $\mathrm{NDF}$ & 48.5 & 52.3 & 1.48 & 0.130 \\
\hline $\mathrm{ADF}$ & 44.2 & 48.2 & 1.29 & 0.080 \\
\hline $\mathrm{CP}$ & 64.0 & 63.1 & 1.02 & 0.345 \\
\hline \multicolumn{5}{|l|}{$\mathrm{N}$ balance, $\mathrm{g} / \mathrm{d}$} \\
\hline $\mathrm{N}$ intake & 514 & 455 & 33.9 & 0.109 \\
\hline $\mathrm{N}$ in feces & 185 & 168 & 14.6 & 0.254 \\
\hline $\mathrm{N}$ in urine & 136 & 121 & 6.1 & 0.126 \\
\hline $\mathrm{N}$ in milk ${ }^{3}$ & 137 & 114 & 11.6 & 0.023 \\
\hline $\mathrm{N}$ balance ${ }^{4}$ & 55.9 & 52.2 & 9.48 & 0.748 \\
\hline
\end{tabular}

were reduced by 11.0 and $11.5 \%$ with TSP, which may show that the reduction of $\mathrm{N}$ in urine with TSP could be partially explained by the lower $\mathrm{N}$ intake. Overall, $\mathrm{N}$ balance was positive and similar between $\mathrm{CON}$ and TSP $(+54.1 \mathrm{~g}$ of $\mathrm{N} / \mathrm{d}$ on average) despite a lower $\mathrm{N}$ excretion in milk for TSP $(-17 \%, P=0.023)$.
Rumen Parameters. Concentrations in $\mathrm{NH}_{3}$ and total VFA were similar between CON and TSP (15.2 and $107.7 \mathrm{mM}$ on average, respectively; Table 6). The VFA profile differed only in acetate proportion, which was higher for TSP $(+6.4$ percentage units; $P=0.031)$, inducing a tendency for a higher acetate-to-propionate

Table 6. Fermentation characteristics and protozoa concentration in the rumen fluid of lactating dairy cows fed a diet containing tea saponin $(\mathrm{n}=7)$

\begin{tabular}{|c|c|c|c|c|}
\hline \multirow[b]{2}{*}{ Item $^{1}$} & \multicolumn{2}{|c|}{$\operatorname{Diet}^{2}$} & \multirow[b]{2}{*}{ SEM } & \multirow[b]{2}{*}{$P$-value } \\
\hline & $\mathrm{CON}$ & TSP & & \\
\hline $\mathrm{NH}_{3}, \mathrm{~m} M$ & 16.2 & 14.2 & 2.90 & 0.657 \\
\hline Total VFA, $\mathrm{m} M$ & 110.8 & 104.6 & 10.32 & 0.675 \\
\hline \multicolumn{5}{|l|}{ VFA profile, $\mathrm{mol} / 100 \mathrm{~mol}$} \\
\hline Acetate $(\mathrm{A})$ & 55.3 & 61.7 & 2.06 & 0.031 \\
\hline Propionate $(\mathrm{P})$ & 23.7 & 20.6 & 1.55 & 0.156 \\
\hline Butyrate (B) & 16.5 & 13.7 & 1.59 & 0.216 \\
\hline Minor $\mathrm{VFA}^{3}$ & 4.32 & 3.98 & 0.384 & 0.474 \\
\hline $\mathrm{A}: \mathrm{P}$ & 2.44 & 3.05 & 0.230 & 0.053 \\
\hline$(\mathrm{A}+\mathrm{B}): \mathrm{P}$ & 3.21 & 3.72 & 0.275 & 0.152 \\
\hline Total protozoa, $\log _{10}$ cells $/ \mathrm{mL}$ & 5.01 & 5.18 & 0.121 & 0.372 \\
\hline \multicolumn{5}{|l|}{ Entodiniomorphs, $\log _{10}$ cells $/ \mathrm{mL}$} \\
\hline Small $(<100 \mu \mathrm{m})$ & 4.97 & 5.10 & 0.127 & 0.476 \\
\hline Large $(>100 \mu \mathrm{m})$ & 3.87 & 4.21 & 0.145 & 0.159 \\
\hline \multicolumn{5}{|l|}{ Holotrichs, $\log _{10}$ cells $/ \mathrm{mL}$} \\
\hline Dasytricha & 2.50 & 2.52 & 0.158 & 0.877 \\
\hline Isotricha & 2.65 & 2.89 & 0.185 & 0.439 \\
\hline
\end{tabular}

${ }^{1}$ Data from 1 sampling day in wk 5 (3.5 h after morning feeding).

${ }^{2} \mathrm{CON}=\operatorname{diet}$ control; TSP $=\operatorname{diet} \mathrm{CON}$ containing $0.52 \%$ tea saponin on a DM basis.

${ }^{3}$ Minor VFA $=$ sum of isobutyrate, isovalerate, valerate, and caproate. 
ratio compared with $\mathrm{CON}(P=0.053)$. Protozoa concentrations and composition were similar between diets, with an average total concentration of $5.1 \log _{10}$ cells/mL.

\section{DISCUSSION}

\section{Reduction of In Vitro Methane Production with Tea Saponin}

In the present in vitro experiment, increasing tea saponin dosage linearly decreased methanogenesis, with a maximum $\mathrm{CH}_{4}$ reduction $(\mathrm{mL} / \mathrm{g}$ of substrate) of $29 \%$ for $0.50 \mathrm{~g} / \mathrm{L}$ of added saponin (i.e., $5.8 \% \mathrm{CH}_{4}$ reduction per $0.1 \mathrm{~g} / \mathrm{L}$ of added saponin). Similarly, using tea saponin obtained from the same supplier, $\mathrm{Hu}$ et al. (2005b) reported a similar linear dose effect of this plant extract on in vitro methanogenesis with a maximum $\mathrm{CH}_{4}$ reduction (mL/g of substrate) of $14 \%$ for $0.24 \mathrm{~g} / \mathrm{L}$ of added saponin (i.e., $5.8 \% \mathrm{CH}_{4}$ reduction per $0.1 \mathrm{~g} / \mathrm{L}$ of added saponin).

Methanogenesis is the final step of feed fermentation in the rumen, and is the main pathway of $\mathrm{H}_{2}$ disposal under most ruminal conditions. Enteric $\mathrm{CH}_{4}$ production may be decreased by an inhibition of $\mathrm{H}_{2}$ production or by a shift in $\mathrm{H}_{2}$ allocation (competition for reducing equivalents), both mechanisms leading to a reduction of $\mathrm{H}_{2}$ availability for methanogenic archaea (Guyader et al., 2015b). In our in vitro experiment, tea saponin may have decreased methanogenesis through both pathways. First, the plant extract linearly reduced protozoa concentration, which are known to produce and supply large amounts of $\mathrm{H}_{2}$ to methanogenic archaea living next to or inside the protozoal cell, through interspecies $\mathrm{H}_{2}$ transfer (Morgavi et al., 2012). A previous meta-analysis demonstrated the linear relationship between rumen protozoa concentration and $\mathrm{CH}_{4}$ emission (Guyader et al., 2014). The toxic in vitro effect of tea saponin $(0.24 \mathrm{~g} / \mathrm{L})$ toward protozoa has also been reported previously $(-16 \%$, cells $/ \mathrm{mL}, \mathrm{Hu}$ et al., 2005b; $-51 \%$, \% of total bacterial $16 \mathrm{~S}$ rDNA, Guo et al., 2008). Second, tea saponin modified VFA profiles by enhancing $\mathrm{H}_{2}$-consuming VFA (propionate; $1 \mathrm{~mol} \mathrm{H}_{2}$ consumed per mole propionate) and decreasing $\mathrm{H}_{2}$-producing VFA (acetate and butyrate; 2 moles $\mathrm{H}_{2}$ produced per mole acetate or butyrate). This result supports the work of $\mathrm{Hu}$ et al. (2005b) and Guo et al. (2008), who showed a reduction of the acetate-to-propionate ratio (from 4.54 to 4.37 and from 3.00 to 2.60, respectively) when using tea saponin up to $0.24 \mathrm{~g} / \mathrm{L}$. Overall, through its effect on protozoa concentration and VFA profile, tea saponin tested in vitro decreased $\mathrm{H}_{2}$ availability for methanogenic archaea, leading to a reduction of methanogenesis.

\section{Absence of Methane Mitigating Effect of Tea Saponin Fed to Lactating Dairy Cows}

After 4 wk of dietary tea saponin supplementation $(0.52 \% \mathrm{DM}), \mathrm{CH}_{4}$ emissions of lactating cows, expressed as grams per kilogram of DMI, increased by $14 \%$. With similar dosage as the present experiment, RamírezRestrepo et al. (2016) and Guyader et al. (2015a) both reported an absence of $\mathrm{CH}_{4}$-mitigating effect of tea saponin fed to large ruminants, whereas previous experiments on sheep (Yuan et al., 2007; Mao et al., 2010; Zhou et al., 2011) showed a significant reduction of methanogenesis. Several factors may explain these discrepancies among studies. For instance, the passage rate of digesta through the rumen can affect enteric $\mathrm{CH}_{4}$ production in ruminants by modulating the time span available for microbial feed fermentation and for tea saponin action (Kumar et al., 2009). Thus, greater passage rate may reduce the $\mathrm{CH}_{4}$-mitigating efficiency of tea saponin. As no previous studies measured this parameter, our hypothesis can only be tested with positively correlated factors such as level of intake (g/ $\mathrm{kg}$ of BW) or proportion of concentrates (Colucci et al., 1984); however, the available literature describing the effect of tea saponin on methanogenesis does not validate our hypothesis. Mao et al. (2010) reported a stronger $\mathrm{CH}_{4}$ reduction $(-27 \%$ with $0.50 \%$ tea saponin in DM) associated with a greater level of intake (37.4 $\mathrm{g} / \mathrm{kg}$ of BW compared with $28.5 \mathrm{~g} / \mathrm{kg}$ of $\mathrm{BW}$ in the present study) suggesting a greater passage rate than the present study. The proportion of concentrates cannot explain differences of response between studies, as similar proportions ( $40 \%$ of DM) were used between the present study and Yuan et al. (2007), Mao et al. (2010), and Zhou et al. (2011).

Similar $\mathrm{CH}_{4}$ emissions (g/d) between CON and TSP were surprising given the reduction in DMI with tea saponin supplementation $(-2.4 \mathrm{~kg} / \mathrm{d})$, as, in contrast, a positive relationship between methanogenesis and DMI has usually been reported in the literature (Reynolds et al., 2011). A greater $\mathrm{H}_{2}$ production with tea saponin may explain the present result. First, tea saponin $(+14 \%$, g/ $\mathrm{kg}$ of DMI) increased rumen acetate proportion $(+6.2$ percentage units), which is known to release $\mathrm{H}_{2}$ in the rumen, the limiting substrate for methanogenic archaea (Janssen, 2010). Modification of fermentation patterns toward nonglucogenic VFA (acetate and butyrate) with tea saponin feeding has also been reported by RamírezRestrepo et al. (2016), whereas Yuan et al. (2007), Mao et al. (2010), and Zhou et al. (2011) did not observe modifications in rumen VFA profile. Second, a numerical increase in total-tract ADF digestibility, which is probably a consequence of a slightly better rumen fer- 
mentation of this fiber component, may also explain the higher proportion of acetate and $\mathrm{H}_{2}$ availability.

Tea saponin was assumed to reduce methanogenesis through an inhibitory effect toward protozoa. However, after 3 wk of supplementation of tea saponin, the total quantity of this $\mathrm{H}_{2}$-producing population remained constant, as well as the quantity of holotrichs, which are suggested as being the largest contributors to methanogenesis (Newbold et al., 2015). The relationship between this plant extract and rumen protozoa concentration still requires further study (Jayanegara et al., 2014); a reduction of protozoa concentrations was reported in small ruminants fed similar dosage (up to $-43 \%$ relative to total bacterial $16 \mathrm{~S}$ rDNA; Mao et al., 2010, Zhou et al., 2011), whereas an increase of protozoal numbers has been observed in cattle supplemented with similar $(+29 \%$, cells $/ \mathrm{mL}$; Guyader et al., 2015a) or lower $\left(+50 \%, \log _{10}\right.$ copy number $/ \mathrm{mL}$; Ramírez-Restrepo et al., 2016) dosage. An adaptation of protozoa to tea saponin may be hypothesized, but Mao et al. (2010) and Zhou et al. (2011) showed that protozoa concentration remained lower in sheep supplemented with tea saponin for 8 wk compared with sheep fed a control diet.

Overall, tea saponin was found to have different effects on rumen microbial profile, without apparent reasons. For instance, similar to Ramírez-Restrepo et al. (2016), Zhou et al. (2011) observed a reduction of Fibrobacter succinogenes $(-80 \%$ relative to total bacterial $16 \mathrm{~S} \mathrm{rDNA}$ ), whereas the same microbial population remained unchanged with similar dosage of tea saponin in Mao et al. (2010). The abundance of Ruminococcus flavefaciens was 100-fold lower in steers fed $0.37 \%$ tea saponin in DM (Ramírez-Restrepo et al., 2016), whereas others (Mao et al., 2010; Zhou et al., 2011) did not observe a modification of this $\mathrm{H}_{2}$-producing bacterial species in sheep fed $0.50 \%$ tea saponin in DM. The effect of tea saponin on methanogenic archaea seems more repeatable, as both Ramírez-Restrepo et al. (2016) and Mao et al. (2010) reported an absence of effect of the plant extract on this population.

Finally, in the present in vivo experiment, the absence of effect of tea saponin on methanogenesis and protozoa concentration, as well as its stimulating effect on acetate production, is in opposition with results observed in the in vitro assay. However, concentrations of tea saponin relative to the medium were relatively close between experiments: the highest dose tested in vitro $(0.50 \mathrm{~g} / \mathrm{L})$ would correspond to a daily intake of $38 \mathrm{~g}$ of tea saponin daily, assuming a rumen liquid content of $75 \mathrm{~L}$ (Brosh et al., 1993). In the in vivo experiment, cows ate an average of $93 \mathrm{~g}$ of tea saponin daily (17.9 $\mathrm{kg}$ of DMI, $0.52 \%$ of tea saponin in DM). Therefore, discrepancy between in vitro and in vivo studies can result from differences in availability of the additive within the rumen related to its rate of absorption and washout from this digestive compartment (Yáñez-Ruiz et al., 2016). Microbial composition, which may affect degradation rates of the active compound, can also be differently affected in both techniques. Loss of diversity is commonly observed in vitro partly due to oxygen exposure during inoculation (Yáñez-Ruiz et al., 2016).

\section{Absence of Saponin Effect on Performances Despite Improved ADF Digestibility}

The effect of tea saponin on total-tract digestibility has been poorly studied. In the present experiment, tea saponin did not modify diet digestibility and $\mathrm{N}$ balance of lactating cows, but it tended to improve ADF digestibility (+4 percentage units). Guyader et al. (2015a) also reported a numerically higher NDF digestibility (+2 percentage units) with the same dosage of tea saponin fed to nonlactating dairy cows. This outcome may be related to the numerically lower $(-12 \%)$ DMI of lactating dairy cows fed this plant extract, given that a reduction of DMI can be associated with lower rumen filling and greater fiber digestibility (Allen, 2000).

In previous work with animals fed ad libitum, DMI was not modified in sheep supplemented with $0.50 \%$ tea saponin in DM (Mao et al., 2010), whereas Ramírez-Restrepo et al. (2016) observed a decrease of DMI (-7\%) with steers fed up to $0.37 \%$ tea saponin in DM. Lower DMI for cattle supplemented with tea saponin may be related to their greater sensitivity to bitter substances (such as saponin) compared with sheep (Cheeke, 1996). In a previous study, cows refused to eat a diet mixed with tea saponin powder, which strongly suggests a palatability issue with this plant extract. However, in the present work, tea saponin was included in pelleted concentrates containing an aroma.

The numerical increase in fiber digestibility was not associated with greater animal performance; tea saponin supplementation reduced milk $(-18 \%)$ and FPCM $(-19 \%)$ production without affecting milk composition. The reduction of milk yield can be explained by the lower DMI between diets. To our knowledge, the effect of tea saponin on lactating performances of dairy cattle has never been studied. A dose-response study of tea saponin effect on lactating performances may be required to complete this work, after solving the possible palatability issue. Inconsistent effects of tea saponin supplementation has been reported on beef cattle and lamb performances. Mao et al. (2010) did not observe differences in growth of lambs supplemented with $0.50 \%$ tea saponin. Li and Powers (2012) reported no effect of low tea saponin dosage $(0.05 \%)$ on the average daily weight gain of steers, whereas a higher dose $(0.11 \%)$ 
reduced the average daily weight gain by $80 \%$ linked to a drop of DMI $(-27 \%)$.

\section{CONCLUSIONS}

In our experimental conditions, tea saponin supplementation reduced lactating performances and DMI. Despite a decrease in methanogenesis in vitro through a linear reduction in protozoa concentrations, the same plant extract $(0.52 \% \mathrm{DM})$ failed to reduce daily $\mathrm{CH}_{4}$ production when fed to lactating dairy cows. This outcome may result from a lack of effect of tea saponin on protozoa concentration in vivo. Given that the promising effects of tea saponin observed in vitro were not confirmed in vivo, this experiment shows once again the importance of in vivo experimentations to develop new $\mathrm{CH}_{4}$-mitigating strategies. Moreover, as tea saponin seems to consistently reduce methanogenesis in sheep, the conditions in which this plant extract might act as a $\mathrm{CH}_{4}$ inhibitor in cattle require further study.

\section{ACKNOWLEDGMENTS}

J. Guyader was the recipient of an INRA-Région Auvergne $\mathrm{PhD}$ scholarship. The authors thank L. Genestoux (UMR1213 Herbivores) for laboratory analyses, as well as INRA's experimental unit (UE1414 Herbipôle, Saint-Genès-Champanelle, France), especially V. Tate, L. Mouly, D. Roux, and S. Rudel for animal care.

\section{REFERENCES}

Allen, M. S. 2000. Effects of diet on short-term regulation of feed intake by lactating dairy cattle. J. Dairy Sci. 83:1598-1624.

AOAC. 1990. Official Methods of Analysis. Vol. 77. Assoc. Off. Anal. Chem., Arlington, VA.

AOAC International. 2005. Official Methods of Analysis. 18th ed. AOAC Int., Arlington, VA.

Arhab, R., R. Abla, M. Aggoun, and H. Zitouni. 2014. Effect of $\mathrm{Ca}-$ mellia sinensis and Trigonella foenum-greacum saponins on in vitro rumen fermentation of vetch-oat hay. Emir. J. Food Agric. 26:723-729.

Brosh, A., Z. Holzer, Y. Aharoni, and D. Levy. 1993. Intake, rumen volume, retention time and digestibility of diets based on poultry litter and wheat straw in beef cows before and after calving. J. Agric. Sci. 121:103-109.

Cheeke, P. R. 1996. Biological effects of feed and forage saponins and their impacts on animal production. Pages 377-385 in Saponins Used in Food and Agriculture. Vol. 405. G. Waller and K. Yamasaki, ed. Plenum Press, New York, NY.

Colucci, P. E., G. K. Macleod, I. McMillan, and W. L. Grovum. 1984. Comparative digestion and digesta kinetics in sheep and cattle. Can. J. Anim. Sci. 64:173-174.

Doreau, M., A. Ferlay, Y. Rochette, and C. Martin. 2014. Effects of dehydrated lucerne and soya bean meal on milk production and composition, nutrient digestion, and methane and nitrogen losses in dairy cows receiving two different forages. Animal 8:420-430.

European Parliament and Council of the European Union. 2010. Directive 2010/63/EU of the European Parliament and of the Council of 22 September 2010 on the protection of animals used for scientific purposes. Accessed Jan. 9, 2017. http://eur-lex.europa. eu/legal-content/EN/ALL/?uri=CELEX:32010L0063

Gerber, P., T. Vellinga, C. Opio, and H. Steinfeld. 2011. Productivity gains and greenhouse gas emissions intensity in dairy systems. Livest. Sci. 139:100-108.

Goel, G., and H. P. S. Makkar. 2012. Methane mitigation from ruminants using tannins and saponins. Trop. Anim. Health Prod. 44:729-739.

Goering, H. K., and P. J. VanSoest. 1970. Forage Fiber Analysis. Agricultural Research Service, USDA, Washington, DC,

Guo, Y. Q., J. X. Liu, Y. Lu, W. Y. Zhu, S. E. Denman, and C. S. McSweeney. 2008. Effect of tea saponin on methanogenesis, microbial community structure and expression of mcrA gene, in cultures of rumen micro-organisms. Lett. Appl. Microbiol. 47:421-426.

Guyader, J., M. Doreau, D. P. Morgavi, C. Gérard, C. Loncke, and C. Martin. 2016. Long-term effect of linseed plus nitrate fed to dairy cows on enteric methane emission and nitrate and nitrite residuals in milk. Animal 10:1173-1181.

Guyader, J., M. Eugène, M. Doreau, D. P. Morgavi, C. Gérard, C. Loncke, and C. Martin. 2015a. Nitrate but not tea saponin feed additives decreased enteric methane emissions in nonlactating cows. J. Anim. Sci. 93:5367-5377.

Guyader, J., M. Eugène, B. Meunier, M. Doreau, D. P. Morgavi, M. Silberberg, Y. Rochette, C. Gérard, C. Loncke, and C. Martin. 2015b. Additive methane-mitigating effect between linseed oil and nitrate fed to cattle. J. Anim. Sci. 93:3564-3577.

Guyader, J., M. Eugène, P. Nozière, D. P. Morgavi, M. Doreau, and C. Martin. 2014. Influence of rumen protozoa on methane emissions in ruminants: a meta-analysis approach. Animal 8:1816-1825.

Holtshausen, L., A. V. Chaves, K. A. Beauchemin, S. M. McGinn, T. A. McAllister, N. E. Odongo, P. R. Cheeke, and C. Benchaar. 2009. Feeding saponin-containing Yucca schidigera and Quillaja saponaria to decrease enteric methane production in dairy cows. J. Dairy Sci. 92:2809-2821.

Hu, W. L., J. X. Liu, J. A. Ye, Y. M. Wu, and Y. Q. Guo. 2005a. Effect of tea saponin on rumen fermentation in vitro. Anim. Feed Sci Technol. 120:333-339.

Hu, W. L., Y. M. Wu, J. X. Liu, Y. Q. Guo, and J. A. Ye. 2005b. Tea saponins affect in vitro fermentation and methanogenesis in faunated and defaunated rumen fluid. J. Zhejiang Univ. Sci. B 6:787-792.

Janssen, P. H. 2010. Influence of hydrogen on rumen methane formation and fermentation balances through microbial growth kinetics and fermentation thermodynamics. Anim. Feed Sci. Technol. 160:1-22.

Jayanegara, A., E. Wina, and J. Takahashi. 2014. Meta-analysis on methane mitigating properties of saponin-rich sources in the rumen: influence of addition levels and plant sources. Asian-australas. J. Anim. Sci. 27:1426-1435.

Kumar, S., A. K. Puniya, M. Puniya, S. S. Dagar, S. K. Sirohi, K Singh, and G. W. Griffith. 2009. Factors affecting rumen methanogens and methane mitigation strategies. World J. Microbiol. Biotechnol. 25:1557-1566.

Li, W., and W. Powers. 2012. Effects of saponin extracts on air emissions from steers. J. Anim. Sci. 90:4001-4013.

Lila, Z. A., N. Mohammed, S. Kanda, M. Kurihara, and H. Itabashi. 2005. Sarsaponin effects on ruminal fermentation and microbes, methane production, digestibility and blood metabolites in steers. Asian-australas. J. Anim. Sci. 18:1746-1751.

Mao, H. L., J. K. Wang, Y. Y. Zhou, and J. X. Liu. 2010. Effects of addition of tea saponins and soybean oil on methane production, fermentation and microbial population in the rumen of growing lambs. Livest. Sci. 129:56-62.

Martin, C., D. P. Morgavi, and M. Doreau. 2010. Methane mitigation in ruminants: From microbe to the farm scale. Animal 4:351-365.

Morgavi, D. P., J. P. Jouany, and C. Martin. 2008. Changes in methane emission and rumen fermentation parameters induced by refaunation in sheep. Aust. J. Exp. Agric. 48:69-72.

Morgavi, D. P., C. Martin, and H. Boudra. 2013. Fungal secondary metabolites from Monascus spp. reduce rumen methane production in vitro and in vivo. J. Anim. Sci. 91:848-860. 
Morgavi, D. P., C. Martin, J. P. Jouany, and M. J. Ranilla. 2012. Rumen protozoa and methanogenesis: Not a simple cause-effect relationship. Br. J. Nutr. 107:388-397.

Newbold, C. J., G. de la Fuente, A. Belanche, E. Ramos-Morales, and N. McEwan. 2015. The role of ciliate protozoa in the rumen. Front. Microbiol. 6:1313.

Oenning, G., M. A. Juillerat, L. Fay, and N.-G. Asp. 1994. Degradation of oat saponins during heat processing - Effect of $\mathrm{pH}$, stainless steel, and iron at different temperatures. J. Agric. Food Chem. 42:2578-2582.

Ogimoto, K., and S. Imai. 1981. Atlas of Rumen Microbiology. Japan Scientific Societies Press, Tokyo, Japan.

Okun, L. B. 2009. Energy and Mass in Relativity Theory. World Scientific Publishing Co. Pte. Ltd., Singapore.

Pen, B., K. Takaura, S. Yamaguchi, R. Asa, and J. Takahashi. 2007. Effects of Yucca schidigera and Quillaja saponaria with or without $\beta$ 1-4 galacto-oligosaccharides on ruminal fermentation, methane production and nitrogen utilization in sheep. Anim. Feed Sci. Technol. 138:75-88.

Pinares-Patiño, C. S. C. Hunt, R. Martin, J. West, P. Lovejoy, and G. Waghorn. 2012. Chapter 1: New Zealand ruminant methane measurement centre, AgResearch, Palmerston North. Pages 9-28 in Technical Manual on Respiration Chamber Designs. C. S. PinaresPatiño and G. Waghorn, ed. Ministry of Agriculture and Forestry, Wellington, New Zealand.

Potts, T. J. 1967. Colorimetric determination of urea in feeds (report of AOAC Committee). J. Assoc. Off. Anal. Chem. 50:56-58.

Ramírez-Restrepo, C. A., C. Tan, C. J. O’Neill, N. López-Villalobos, J. Padmanabha, J. K. Wang, and C. S. McSweeney. 2016. Methane production, fermentation characteristics, and microbial profiles in the rumen of tropical cattle fed tea seed saponin supplementation. Anim. Feed Sci. Technol. 216:58-67.

Reynolds, C. K., L. A. Crompton, and J. A. N. Mills. 2011. Improving the efficiency of energy utilisation in cattle. Anim. Prod. Sci. 51:6-12.
Shen, J. S., Z. Chai, L. J. Song, J. X. Liu, and Y. M. Wu. 2012. Insertion depth of oral stomach tubes may affect the fermentation parameters of ruminal fluid collected in dairy cows. J. Dairy Sci. 95:5978-5984.

Tarade, K. M., R. S. Singhal, R. V. Jayram, and A. B. Pandit. 2006. Kinetics of degradation of saponins in soybean flour (Glycine max.) during food processing. J. Food Eng. 76:440-445.

Wang, J. K., J. A. Ye, and J. X. Liu. 2012. Effects of tea saponins on rumen microbiota, rumen fermentation, methane production and growth performance-A review. Trop. Anim. Health Prod. 44:697-706.

Weatherburn, M. W. 1967. Phenol-hypochlorite reaction for determination of ammonia. Anal. Chem. 39:971-974.

Wei, M. L., L. P. Ren, Z. M. Zhou, and Q. X. Meng. 2012. Effect of addition of three plant extracts on gas production, ruminal fermentation, methane production and ruminal digestibility based on an in vitro technique. J. Anim. Vet. Adv. 11:4304-4309.

Williams, A. G., and G. S. Coleman. 1992. The Rumen Protozoa. Springer-Verlag, New York, NY.

Yáñez-Ruiz, D. R. A. Bannink, J. Dijkstra, E. Kebreab, D. P. Morgavi, P. O'Kiely, C. K. Reynolds, A. Schwarm, K. J. Shingfield, Z. $\mathrm{Yu}$, and A. N. Hristov. 2016. Design, implementation and interpretation of in vitro batch culture experiments to assess enteric methane mitigation in ruminants-A review. Anim. Feed Sci. Technol. $216: 1-18$.

Yuan, Z. P., C. M. Zhang, L. Zhou, C. X. Zou, Y. Q. Guo, W. T. Li, J. X. Liu, and Y. M. Wu. 2007. Inhibition of methanogenesis by tea saponin and tea saponin plus disodium fumarate in sheep. J. Anim. Feed Sci. 16:560-565.

Zhou, Y. Y., H. L. Mao, F. Jiang, J. K. Wang, J. X. Liu, and C. S. McSweeney. 2011. Inhibition of rumen methanogenesis by tea saponins with reference to fermentation pattern and microbial communities in Hu sheep. Anim. Feed Sci. Technol. 166-167:93-100. 